\title{
Pengaruh Price To Book Value, Earning Per Share Dan Debt To Equity Rasio terhadap Harga Saham Bank Umum Swasta Nasional
}

\author{
Sochib \\ Program Studi Akuntansi, STIE Widya Gama Lumajang \\ Email: sochib.ak@gmail.com
}

https://doi.org/10.30741/wiga.v9i1.408

I N F O A R T I K E L

Tanggal masuk :

28 Februari 2019

Tanggal Revisi :

19 Maret 2019

Tanggal Diterima :

31 Maret 2019

\section{A B S T R A K}

Harga saham menjadi acuan bagi banyak kalangan di Bursa Efek Indonesia (BEI), terutama investor dan calon investor yang mempunyai ekspektasi terhadap harga saham di akhir hari penutupan Bursa Efek. Investor bergantung pada harga saham di bursa karena ini merupakan bagian kesejahteraan pada saat investor bersedia melepaskan dananya ke bursa. Manajemen perusahaan juga mempunyai kewajiban untuk menginformasikan kinerjanya selama kurun waktu tertentu. Kinerja manajemen perusahaan akan tercermin pada harga saham pada penutupan bursa. Ada beberapa faktor yang bisa mempengaruhi kinerja manajemen dan harga saham, seperti PBV, EPS, dan DER. Karena faktor ini secara fundamental akan memberikan dorongan terjadinya harga saham di bursa. Manajemen sangat berkepentingan dengan indikator seperti PBV, EPS, dan DER dapat diketahui tingkat keuntungan yang diperoleh perusahaan, kemampuan perusahaan mendayagunakan aset yang dimiliki. Penelitian ini mempunyai tujuan untuk menguji secara empiris pengaruh PBV, EPS, dan DER pada harga saham Bank Umum Swasta Nasional. Peneliti menggunakan 20 sampel sektor perbankan umum swasta nasional yang terdaftar di BEI periode 2014-2016 sehingga diperoleh 60 pengamatan. Hipotesis diuji dengan menggunakan analisis regresi yang dapat digunakan untuk memprediksi kondisi beberapa tahun ke depan setelah mengetahui besaran pengaruh variabel independennya. Hasil yang diperoleh dalam penelitian ini bahwa PBV, EPS dan DER berpengaruh terhadap harga saham. Diharapkan dari hasil penelitian ini dapat memberikan kontribusi dalam pengembangan Ilmu Manajemen Keuangan di Indonesia.

Kata kunci : PBV, EPS, DER, Harga Saham 
$E P S$, and DER, it can be seen the level of profits obtained by the company, the ability of the company to utilize the assets it owns. This study aims to empirically examine the effect of $P B V, E P S$, and DER on the share price of National Private Commercial Banks. The researcher used 20 samples of the national private banking sector listed on the Indonesian Stock Exchange for the 2014-2016 period to obtain 60 observations. The hypothesis is tested using regression analysis which can be used to predict the condition of the next few years after knowing the magnitude of the effect of the independent variables. The results obtained in this study that PBV, EPS and DER affect stock prices. It is expected that the results of this study can contribute to the development of Financial Management Sciences in Indonesia.

Keywords: PBV, EPS, DER, Stock Price

\section{PENDAHULUAN}

Manajemen mempunyai kewajiban untuk meningkatkan kemakmuran para pemegang saham sebagai imbalan atas keputusan investor mengivestasikan modalnya. Pentingnya harga saham bagi suatu entitas tidak hanya untuk pemupukan permodalan perusahaan semata, melainkan lebih dari itu bahwa harga saham menjadi bagian penting dari kesejahteraan dan kemakmuran pemegang saham. Bagi investor bahwa harga saham menjadi ukuran untuk menilai kinerja perusahaan selama kurun waktu tertentu, misalnya setahun atau mungkin beberapa tahun ke depan. Investor punya harapan pada prospek perusahaan di masa yang akan datang sebagai imbalan atas investasi yang telah dilakukan pada perusahaan. Bilamana perusahaan mendapatkan keuntungan yang cukup akan tercermin pada nilai perusahaan, dan tercermin pula pada harga saham.

Tetapi harga saham pada setiap waktu berfluktuasi mengikuti perkembangan fundamental perusahaan. Harga saham akan tetap berubah, yang kadang-kadang besar dan cepat, tetapi hal ini secara sederhana mencerminkan kondisi dan pengharapan yang berubah. Ada waktu ketika saham terus bereaksi selama beberapa bulan terhadap perkembangan yang menguntungkan dan yang tidak menguntungkan. Faktor lain di luar faktor fundamental perusahaan juga mempengaruhi fluktuasi harga saham. Faktor tersebut bersifat eksternal yang akan mempengaruhi permintaan dan penawaran para investor. Harga saham menjadi perhatian manajemen terutama sebagai upaya untuk meningkatkan kemakmuran pemegang saham. Keberhasilan dalam menghasilkan keuntungan akan memberikan kepuasan bagi investor yang rasional. Harga saham yang cukup tinggi akan memberikan keuntungan yaitu berupa capital gain dan citra yang baik bagi manajemen untuk memudahkan manajemen mendapatkan dana yang cukup banyak dari luar perusahaan.

Penelitian yang mengungkap harga saham, seperti peneliti (Indriana, 2012) yang meneliti pengaruh Price to Book Value, Earning Per Share dan Debt to Equity Rasio perusahaan Consumer Goods periode 2008-2012 yang menghasilkan kesimpulan bahwa EPS berpengaruh terhadap harga saham sedangkan PBV dan DER tidak berpengaruh. (Ginting \& Suriany, 2013) yang menganalisis faktor yang mempengaruhi harga saham perusahaan manufaktur menyatakan bahwa PBV berpengaruh terhadap harga saham. (cahyanngrum, Yustina W., Antikasari, 2017) yang meneliti perusahaan sektor keuangan menyimpulkan bahwa PBV dan EPS berpengaruh terhadap harga saham, (Hadianto, 2008) yang meneliti perusahaan perdagangan besar dan ritel menyimpulkan EPS dan PER berpengaruh positif. (Dewi \& Suaryana, 2013) yang meneliti perusahaan Food dan Beverage menyimpulkan EPS, PBV berpengaruh signifikan positif dan DER berpengaruh signifikan negatif.

Namun demikian dari beberapa penelitian tersebut masih adanya reseach gab hasil-hasil penelitiannya. Oleh karena itu penelitian terhadap faktor PBV, EPS dan DER masih menjadi penting dilakukan penelitiannya. Investor dan calon investor memiliki harapan terhadap 
fundamental perusahaan untuk dipakai sebagai dasar pengambilan keputusan investasinya. Researh Gap tersebut memberikan motivasi utama bagi peneliti untuk mengkaji lebih dalam tentang faktor yang mempengaruhi harga saham dengan obyek dan periode yang berbeda dari penelitian sebelumnya. Penelitian ini dimotivasi oleh Dewi yang meneliti Pengaruh Earning Per Share, Debt to Equity Ratio, dan Price to Book Value terhadap Harga Saham Perusahaan Food and Beverage. Hasil penelitiannya bahwa EPS dan PBV berpengaruh signifikan positif, dan DER berpengaruh signifikan negatif. Price to Book Value dan Price Earning Ratio memberikan makna bahwa harga saham suatu entitas di Bursa Efek Indonesia pada kondisi Over valued atau Under valued. Pasar saham memberikan reaksi dengan harga yang normal dan bisa juga pasar bereaksi dengan harga saham premium karena prospek perusahaan di masa yang akan datang akan lebih baik.

Masalah yang dikemukakan dalam penelitian ini (research problem) adalah faktor fundamental apakah yang dapat mempengaruhi harga saham bank umum swasta nasional di Indonesia ? Pertanyaan penelitian atas masalah penelitian tersebut di atas adalah: Apakah Price to Book Value, Earning Per Share dan Debt to Equity Rasio mempengaruhi harga saham penutupan di Bursa Efek Indonesia ?. Oleh karena itu, research problem dalam penelitian ini adalah apakah Price to Book Value, Earning Per Share dan Debt to Equity Ratio mempengaruhi harga saham penutupan pada Bank Umum Swasta Nasional Indonesia. Dengan mengambil tema Pengaruh Price to Book Value, Earning Per Share, dan Debt to Equity Ratio terhadap Harga Saham Bank Umum Swasta Nasional Yang Terdaftar di Bursa Efek Indonesia 2014-2016. Hasil-hasil penelitian empirik ini diharapkan dapat memberikan kontribusi pada pengembangan teori, terutama kajian akuntansi dan manajemen investasi di pasar modal. Temuan penelitian ini juga diharapkan dapat memberikan manfaat dalam memberikan masukan kepada investor dan calon investor, maupun manajemen perusahaan, praktisi bisnis dan analis keuangan dalam upaya memahami akuntansi dan manajemen investasi untuk meningkatkan kemakmuran pemegang saham sehingga harga saham terdorong naik di pasar modal dan kemakmuran pemegang saham terpenuhi.

Saham menjadi bagian ekuitas perusahaan perseroan yang sudah go public di pasar modal dan saham itu menjadi bukti kepemilikan seseorang terhadap sebuah entitas. Saham mempunyai harga yang selalu bergerak mengikuti perkembangan kinerja manajemen dan kekuatan permintaan dan penawaran calon investor. Dalam waktu jangka panjang, harga saham di pasar mencerminkan kinerja perusahaan sendiri. Perusahaan yang kinerjanya positif kemungkinan memperoleh laba dengan kenaikan yang signifikan dan membagikan dividen yang relatif besar. Dividen yang cukup besar akan mendorong calon investor membeli saham tersebut sehingga harga saham terdorong naik. Faktor lain di luar perusahaan, bisa juga mendorong fluktuasi harga saham yang terjadi di pasar seperti kondisi sosial masyarakat, politik, ekonomi dan keamanan.

Permintaan terhadap saham yang relatif kuat dibandingkan dengan penawaran di pasar mau,dal akan mendorong harga saham lebih tinggi lagi. Pebisnis saham lebih tertarik dengan kondisi harga saham yang mengalami kenaikan atau tren naik. Peluang tren harga naik ini memberikan kesempatan pebisnis saham memperoleh capital gain atas transaksi sahamnya. Nilai pasar adalah harga saham yang terjadi di pasar bursa pada saat tertentu yang ditentukan oleh pelaku pasar. Harga saham yang terjadi di pasar bursa pada saat tertentu ditentukan oleh pelaku pasar dan tekanan permintaan dan penawaran saham yang bersangkutan di pasar modal. Memaksimalkan harga saham sangat menguntungkan masyarakat, khususnya investor.

Price to Book Value dapat digunakan sebagai dasar bagi investor di pasar modal untuk pertimbangan pengambilan keputusan investasi. Price to Book Value merupakan nilai buku saham setelah memperhatikan ekuitas yang dimiliki perusahaan. Kondisi PBV dengan nilai di atas satu memberikan gambaran harga saham berada pada posisi di atas harga buku saham tersebut atau saham dalam kondisi over load. Kondisi lain bisa juga PBV berada di bawah satu, berarti harga 
saham di bawah harga bukunya berarti under load. (Budiman, 2017) mengemukakan Price to Book Value $(P B V)$ merupakan harga saham per lembar dibagi dengan nilai buku per lembar. $\mathrm{H}_{1}$ : Terdapat pengaruh Price to Book Value terhadap Harga Saham

Earning Per Share merupakan pendapatan per lembar saham setelah memperhatikan laba bersih yang diperoleh perusahaan. Investor memerlukan informasi ini karena Earning Per Share menjadi inkasi pendapatan yang akan diperoleh investor atas kepemilikan saham perusahaan. Earning Per Share dihitung dengan membagi laba bersih dengan jumlah saham beredar (Budiman, 2017). Earning Per Share yang rendah memberikan informasi kepada para investor bahwa imbalan yang diperoleh investor juga rendah. Kondisi ini akan dires[pon oleh pasar dengan adanya penawaran saham yang lebih besar dari permintaan saham yang mengakibatkan harga saham turun.

$\mathrm{H}_{2}$ : Terdapat pengaruh Earning Per Share terhadap Harga Saham

Debt to Equity Ratio merupakan rasio yang menggunakan hutang dan ekuitas untuk mengukurnya. Rasio ini digunakan untuk mengukur tingkat realisasi utang terhadap total shareholder's equity yang dimiliki perusahaan. Persentase penyediaan dana oleh pemegang saham terhadap pemberi pinjaman. Semakin tinggi rasio, semakin rendah pendanaan perusahaan yang disediakan oleh pemegang saham. Dari perspektif kemampuan membayar kewajiban jangka panjang, semakin rendah rasio akan semakin baik kemampuan perusahaan dalam membayar kewajiban jangka panjangnya. Semakin tinggi DER menunjukkan komposisi total hutang (jangka pendek dan jangka panjang) semakin besar dibanding dengan total modal sendiri, sehingga berdampak semakin besar beban perusahaan terhadap pihak luar (kreditur). Meningkatnya beban terhadap kreditur menunjukkan sumber modal perusahaan sangat tergantung dengan pihak luar. Selain itu besarnnya beban hutang yang ditanggung perusahaan dapat mengurangi jumlah laba yang diterima perusahaan. Kenaikan DER dapat mempengaruhi pertumbuhan laba karena adanya beban Bunga yang harus di bayarkan.

$\mathrm{H}_{3}$ : Terdapat pengaruh Debt to Equity Ratio terhadap Harga Saham

\section{METODE PENELITIAN}

Populasi penelitian ini adalah perusahaan perbankan yakni bank umum swasta nasional yang terdaftar di Bursa Efek Indonesia (BEI), dengan periode pengamatan penelitian dilakukan mulai tahun 2014-2016. Obyek penelitian ini berupa variabel Price to Book Value, Earning Per Share, Debt to Equity Ratio dan Harga Saham. Sampel yang digunakan dalam penelitian ini ditarik dengan metode pengambilan sampel purposive sampling dimana pengambilan sampel dilakukan berdasarkan kriteria sebagai berikut : (a) Bank Umum Swasta Nasional yang terdaftar di Bursa Efek Indonesia dan menerbitkan laporan tahunan untuk periode 2014-2016. (b) Memiliki data yang lengkap mengenai PBV, EPS, DER dan Harga Saham penutupan akhir tahun. Penelitian ini memperoleh data dari Bursa Efek Indonesia (BEI) melalui situs Bursa Efek Indonesia (BEI) dengan alamat situs :http;//www.idx.co.id dan laporan keuangan perusahaan perdagangan besar sampel yang terdapat dalam Indonesia Capital Market Directory (ICMD) Bursa Efek Indonesia. Penelitian pengaruh variabel yang diamati menggunakan regresi berganda atau pola pengaruh antara variabel independen dan variabel dependen.

Data yang diperoleh dari penelitian disajikan dengan cara dan bentuk statistik deskriptif yang akan menjelaskan mengenai karakteristik responden khususnya dalam hubungannya dengan variabelvariabel penelitian. Terutama variabel-variabel yang dihipotesiskan dalam penelitian sebagai dugaan yang sedang dipikirkan oleh peneliti. Sebelum dilakukan uji hipotesis untuk menentukan pengaruh suatu variabel maka diperlukan langkah awal analisis regresi. Menurut (Yamin, 2009) langkah awal analisis regresi adalah pemeriksaan terhadap asumsi yang meliputi: pengujian normalitas residual, tidak adanya problem heteroskedastisitas pada residual dan tidak adanya problem autokorelasi pada residual. 
Statistik deskriptif dalam penelitian digunakan untuk menganalisis data dengan cara mendeskripsikan atau menggambarkan data yang telah terkumpul sebagaimana adanya tanpa bermaksud membuat kesimpulan yang berlaku untuk umum atau generalisasi (Sugiyono, 2015). Informasi yang diperoleh dalam statistik deskriptif memberikan gambaran terhadap variabelvariabel yang sedang dilakukan penelitian. Dalam penelitian ini variabelnya terdiri atas variabel independen yakni Price to Book Value, Earning Per Share, Debt to Equity Rasio dan variabel dependennya yakni Harga Saham. Deskripsi masing-masing variabel tersebut disajikan dalam bentuk frekuensi absolut yang menyatakan maksimum, minimum, mean, dan standar deviasi. Descriptive Statistics menggambarkan nilai rata-rata dan standar deviasi dari variabel dependen dan independen (Yamin, 2009)

Asumsi analisis regresi disebut juga dengan asumsi klasik yang dimaksudkan untuk mengetahui apakah penggunaan model regresi linier berganda dalam menganalisis data yang telah ada memenuhi persyaratan asumsi klasik dan menghasilkan nilai estimasi yang Best Linier Unbiased Estimator (BLUE). Beberapa Asumsi klasik yang harus dipenuhi dalam penelitian analisis regresi berganda (Yamin, 2009) antara lain : Normality of residual, Independence of residual atau tidak adanya problem autokorelasi, Non multikolinier atau tidak adanya multikolinearitas, Homoscedasticity of residual atau tidak adanya problem heteroskedastisitas.

Asumsi dalam penelitian yang menggunakan statistik parametrik yakni harus dipenuhinya asumsi multivariate normality. Asumsi normality merupakan asumsi yang menyatakan bahwa setiap variabel penelitian merupakan variabel yang memiliki distribusi normal. Tujuan Uji normalitas untuk memastikan apakah dalam model regresi, variabel dependen dan variabel independen mempunyai distribusi normal atau tidak. Pengujian normalitas data dideteksi dengan menggunakan grafik Normal Probability Plot atau grafik P-Plot. Deteksi normalitas dengan melihat penyebaran data-data atau titik-titik pada sumbu diagonal dari grafik. Penyebarannya data yang normal mengikuti garis diagonal dan tidak menjauh dari sekitarnya. Dasar pengambilan keputusan adalah (Santoso, 2015) : a. Jika data menyebar di sekitar garis diagonal dan mengikuti arah garis diagonal, maka model regresi memenuhi asumsi normalitas. b. Jika data menyebar jauh dari garis diagonal dan tidak mengikuti arah garis diagonal, maka model regresi tidak memenuhi asumsi normalitas.

Multikolinieritas mempunyai arti adanya hubungan linier yang sempurna atau pasti diantara beberapa atau semua variabel independen dari model regresi. Teknik yang dapat dipakai untuk multikolinieritas, diantaranya dengan menggunakan Variance Inflation Factor (VIF). Dikatakan multikolinier apabila VIF di sekitar angka 10 (Santoso, 2015). Bilamana variabel jauh dibawah angka 10 atau VIF<10, dapat diartikan tidak terjadi multikolinier, dan sebaliknya bilamana nilai VIF jauh diatas angka 10 atau VIF>10 maka terjadi multikolinier. VIF yang semakin tinggi, semakin besar peluang untuk terjadinya multikolinieritas antar variabel independen. Pengujian multikolinearitas bertujuan untuk menguji model regresi apakah terjadi adanya korelasi variabel independen dengan variabel independen yang lainnya. Model regresi yang baik seharusnya tidak terjadi korelasi diantara variabel independen (Ghozali, 2016).

Heterokedastisitas menunjukkan varian dari residual yang tidak sama dari satu pengamatan ke pengamatan yang lain dalam suatu penelitian. Pengujian heterokedastisitas dideteksi dengan melihat ada tidaknya pola tertentu pada grafik scatterplot. Model regresi yang baik adalah yang homokedastisitas atau tidak terjadi heterokedastisitas (Ghozali, 2016). Kriteria terjadi atau tidaknya heterokedastisitas antara lain (Santoso, 2015) : a. Apabila ada pola tertentu, titik-titik (point-point) yang ada membentuk suatu pola tertentu yang teratur (bergelombang, menyebar, dan menyempit), maka telah terjadi heterokedastisitas. b. Apabila tidak ada pola yang jelas, serta titiktitik menyebar di atas dan di bawah angka 0 (nol) pada sumbu Y, maka tidak terjadi heterokedastisitas. 
Pengujian autokorelasi dilakukan untuk memastikan apakah dalam sebuah model regresi linier terdapat korelasi antara kesalahan pengganggu pada periode t dengan kesalahan pada periode $\mathrm{t}-1$. Model regresi yang baik adalah regresi yang bebas dari autokorelasi. Autokorelasi pada sebagian besar kasus ditemukan pada regresi yang datanya time series. Deteksi apakah terdapat autokorelasi atau tidak dapat digunakan Durbin-Watson $(D-W)$ yang umumnya menggunakan patokan sebagai berikut : angka D-W dibawah -2 berarti ada autokorelasi positif, angka D-W diantara -2 sampai +2 berarti tidak ada outokorelasi, angka $\mathrm{D}-\mathrm{W}$ di atas +2 berarti ada outokorelasi negatif (Santoso, 2015).

\section{HASIL DAN PEMBAHASAN}

Descriptive Statistics pada tabel 1 dapat memberikan informasi secara deskriptif tentang variabelvariabel yang sedang diteliti. Penelitian dilakukan dengan 60 pengamatan mulai tahun 2014-2016 terhadap variabel Price to Book Value, Earning Per Share, Debt to Equity Ratio dan Harga Saham Penutupan pada Bank Umum Swasta Nasional.

Tabel 1. Descriptive Statistics

\begin{tabular}{llllll}
\hline & N & Minimum & Maximum & Mean & $\begin{array}{l}\text { Std. } \\
\text { Deviation }\end{array}$ \\
\hline Price To Book Value & 60 & $-0,66$ & 0,61 & 0,0027 & 0,30335 \\
Earning Per Share & 60 & 0,12 & 2,92 & 1,5598 & 0,65523 \\
Debt To Equity Rasio & 60 & 0,51 & 1,06 & 0,7618 & 0,13034 \\
Harga Saham & 60 & 1,81 & 4,19 & 2,771 & 0,58292 \\
\hline
\end{tabular}

Sumber : Data Diolah

Hasil uji statistik deskriptif pada tabel 1 Pertama, Price to Book Value mempunyai nilai minimum -0,66 terdapat pada PT. Bank Victoria Internasional,Tbk pada tahun 2016, sedangkan nilai maksimum 0,61 terdapat pada PT Bank Central Asia, Tbk pada tahun 2014 dengan nilai rata-rata 0,0027 dan standar deviasi sebesar 0,30335. Kedua, Earning Per Share mempunyai nilai minimum 0,12 terdapat pada PT. Bank China Contruction Bank Indonesia,Tbk tahun 2016, sedangkan nilai maksimum 2,92 terdapat pada PT Bank Central Asia,Tbk tahun 2016 dengan nilai rata-rata 1,55 dan standar deviasi sebesar 0,65. Debt to Equity Ratio mempunyai nilai minimum 0,51 terdapat pada PT Bank Woori Saudara Indonesia 1906,Tbk pada tahun 2014, sedangkan nilai maximum 1,06 terdapat pada PT. Bank Bukopin,Tbk pada tahun 2015 dengan nilai rata-rata 0,76 dan standar deviasi sebesar 0,13. Sedangkan harga saham penutupan mempunyai nilai minimum 1,81 terdapat pada PT Bank Artha Graha Indonesia, Tbk pada tahun 2015 dan nilai maksimum 4,19 terdapat pada PT Bank Central Asia,Tbk pada tahun 2016.

Analisis regresi dalam penelitian model regresi mensyaratkan adanya pengujian asumsi klasik yang meliputi pengujian normalitas residual, tidak adanya problem keteroskedastisitas dan autokorelasi pada residual (Yamin, 2009). Beberapa uji klasik dalam penelitian ini telah memenuhi persyaratan yang ditentukan, normalitas, keteroskedastisitas, autokorelasi dan multikolinieritas. Sedangkan hasil regresi yang disajikan pada tabel dibawah merupakan uji t untuk mengukur pengaruh Price to Book Value, Earning Per Share, dan Debt to Equity Equity terhadap Harga Saham. Uji t digunakan untuk menguji signifikansi koefisien regresi secara parsial dari variabel independennya (Ghozali, 2016). 
Tabel 2. Coefficients

\begin{tabular}{llllll}
\hline & B & Std. Error & Beta & t & Sig. \\
\hline Price To Book Value & 0,831 & 0,071 & 0,432 & 11,741 & 0,000 \\
Earning Per Share & 0,640 & 0,033 & 0,719 & 19,506 & 0,000 \\
Debt To Equity Rasio & $-0,690$ & 0,163 & $-0,154$ & $-4,236$ & 0,000 \\
\hline
\end{tabular}

Sumber : Data Diolah

Hasil regresi dalam penelitian ini menunjukkan bahwa variabel Price to Book Value (PBV) mempunyai nilai $p 0,000<0,05$ yang berarti variabel ini berpengaruh signifikan terhadap harga saham bank umum swasta nasional yang terdaftar di Bursa Efek Indonesia periode 2014-2016. Penelitian ini sejalan dengan analisis Price to Book Value merupakan salah satu teknik analisis fundamental yang menentukan apakah harga sebuah saham mahal atau tidak (Budiman, 2017). Hasil penelitian ini mendukung penelitian yang dilakukan sebelumnya antara lain, Dewi (2012), Ginting (2012), Cahyaningrum (2014) bahwa Price to Book Value berpengaruh signifikan positif terhadap harga saham. Peneliti Indriana (2012) yang meneliti perusahaan Consumer Goods menyimpulkan Price to Book Value tidak berpengaruh terhadap harga saham.

Price to Book Value memberikan informasi kepada calon investor bahwa harga saham yang terjadi di Bursa Efek menunjukkan berapakalinya dari harga buku saham. Bilamana nilai Price to Book Value di bawah angka 1 berarti harga saham posisinya berada di bawah nilai buku saham atau under valued, dan sebaliknya bila di atas angka 1 berarti harga saham berada di atas harga bukunya. Sebagai investor fundamental cenderung menyukai harga pasar yang sedang undervalued, karena investor akan menyimpannya saham tersebut untuk beberapa periode tanpa melihat fluktuasi harga yang sifatnya jangka pendek.

Hasil regresi Earning Per Share terhadap harga saham dalam penelitian ini mempunyai nilai $p$ $0,000<0,05$ yang berarti variabel ini berpengaruh signifikan terhadap harga saham bank umum swasta nasional yang terdaftar di BEI periode 2014-2016. Penelitian ini mendukung penelitian sebelumnya, antara lain yang dilakukan oleh Dewi (2013, Cahyaningrum (2017), (Badruzaman, 2017) yang meneliti pengaruh EPS terhadap harga saham. Earning per share menandakan seberapa besar pendapatan per lembar saham yang akan diterima pemegang saham. Bilamana dikaitkan dengan harga pasar saham saat itu maka akan diperoleh informasi berapa kalinya harga saham dengan pendapatan per lembar saham. EPS merupakan laba bersih per lembar saham dan menunjukkan kinerja perusahaan dalam waktu tertentu.

Hasil regresi Debt to Equity Ratio terhadap harga saham dalam penelitian ini mempunyai nilai $p$ $0,000<0,05$ dengan arah minus yang berarti variabel ini berpengaruh signifikan terhadap harga saham penutupan di Bursa Efek pada bank umum swasta nasional dengan arah negatif. Penelitian ini memberikan hasil yang sama dengan penelitian yang dilakukan sebelumnya antara lain, Dewi (2013) yang meneliti perusahaan Food and Beverage menemukan Debt to Equity Ratio berpengaruh signifikan negatif. Tetapi penelitian ini berbeda dengan peneliti Indriana yang menemukan Debt to Equity Ratio tidak berpengaruh pada harga saham penutupan di Bursa Efek pada perusahaan Consumer Goods. Secara fundamental bahwa kinerja perusahaan akan mempengaruhi harga saham penutupan, tetapi juga dipengaruhi permintaan dan penawaran yang terjadi saat itu. Posisi leverage yang tinggi bagi perbankan memberikan potensi dan peluang untuk meningkatkan layanan perbankan, terutama ekspansi kredit. Dengan ekspansi kredit yang dilakukan bank maka bank akan dapat meningkatkan perolehan laba melalui hasil bunga yang 
diterima dari debitur. Karena fungsi bank secara umum yakni menghimpun dana dari masyarakat dan menyalurkannya kepada masyarakat yang membutuhkan atau fungsi intermediasi.

\section{KESIMPULAN}

Kesimpulan hasil penelitian ini bahwa Price to Book Value, Earning per share, Debt to Equity Ratio, dan Harga Saham penutupan Bursa Efek Indonesia bank umum swasta nasional yang terdaftar di BEI 2014-2016 yaitu Price to Book Value (PBV), Earning Per Share (EPS) berpengaruh signifikan positif terhadap Harga Saham penutupan di Bursa Efek Indonesia. Dan Debt to Equity Ratio (DER) berpengaruh signifikan negatif terhadap harga saham penutupan di Bursa Efek Indonesia. Hasil penelitian ini sebagai bukti empiris bahwa terdapat banyak variabelvariabel yang menjadi faktor pengaruh terhadap harga saham penutupan. Penelitian ini diharapkan dapat menyumbangkan manfaat yang kondusif bagi pengelola perbankan dalam upaya mempertahankan harga saham di Bursa Efek Indonesia (BEI). Dan bagi investor dan calon investor saham dapat digunakan sebagai panduan untuk mengalisis saham. Dalam penelitian ini masih terdapat keterbatasan sehingga menjadi ruang tersendiri bagi peneliti lain untuk melakukan penelitian, antara lain mengenai : Sampel pengamatan yang digunakan dalam penelitian dan variabel yang diteliti masih perlu diperluas.

\section{DAFTAR PUSTAKA}

Badruzaman, J. (2017). PENGARUH EARNING PER SHARE TERHADAP HARGA. Jurnal Akuntansi, 12 .

Budiman, R. (2017). Investing is Easy, Teknik Analisa dan Strategi Investasi Saham untuk Pemula (Pertama). Jakarta: PT Elex Media Komputindo.

cahyanngrum, Yustina W., Antikasari, T. W. (2017). Pengaruh Earning Per Share, Price To Book Value, Return On Asset, Dan Return On Equity Terhadap Harga Saham Sektor Keuangan. Jurnal Economia, 13(2), 2-10.

Dewi, P. D. A., \& Suaryana, I. G. N. A. (2013). Pengaruh Eps, Der, Dan Pbv Terhadap Harga Saham. E-Jurnal Akuntansi, 1, 215-229.

Ghozali, I. (2016). Aplikasi Analisis Multivariete dengan Program IBM SPSS 23 (8th ed.). Semarang: Badan Penerbit Universitas Diponegoro.

Ginting, S., \& Suriany. (2013). Analisis Faktor-Faktor Yang Mempengaruhi Harga Saham Pada Perusahaan Manufaktur. Jurnal Wira Ekonomi Mikroskil, 3, 61-70.

Indriana, D. D. (2012). PENGARUH FAKTOR-FAKTOR FUNDAMENTAL TERHADAP HARGA SAHAM DALAM SEKTOR CONSUMER GOODS YANG, (5).

Santoso, S. (2015). Menguasai SPSS 22 From Basic to Expert Skills. Jakarta: PT Elex Media Komputindo.

Sugiyono. (2015). Metode Penelitian Kuantitatif, Kualitatif dan RD. Bandung: Alfabeta.

Yamin, S. (2009). SPSS COMPLETE, Teknik Analisis Statistik Terlengkap. (Ishardini Dewi J, Ed.) (pertama). Jakarta: Salemba Empat. 